\title{
Articles
}

\section{DECLINING GERMAN EXPORT PRICES DUE TO INCREASED COMPETITION FROM NEWLY INDUSTRIALIZING COUNTRIES - EVIDENCE FROM GERMANY AND THE CEECS}

\author{
Sebastian Gundel*
}

\begin{abstract}
:
In this paper, the export demand and supply of German manufacturing industry is estimated for the period 1993 to 2005 . The Johansen procedure $(1991,1994)$ is applied to estimate the long-run relationship in a VECM. Special attention is paid to the development of the German export prices being exposed to the competitive environment of fast growing countries like Hungary, the Czech Republic and Poland. Since they offer similar high-technology products on the international export markets and are gaining the market share, German export prices are under downward pressure. The results show that German export prices grow at a slower pace than that of the competitors and that they are negatively influenced by the growing market share of the CEECs. On the export demand side, the empirical picture corresponds to the theoretical one displaying a less unity income elasticity of demand indicating the decreasing market share for German manufactures in the long run.
\end{abstract}

Keywords: Manufactured Exports, Competition, Cointegration, VECM

JEL Classification: C32, F10, F14

\section{Introduction}

In an open economy like Germany, the macroeconomic environment is heavily influenced by the development of international trade patterns. In Germany, the fear of decreasing welfare due to globalization, especially caused by the growing impact of the New EU Member States ${ }^{1}$ (Poland - PL, the Czech Republic - CR and Hungary - HU, i.e.

* Center of Applied Economics Muenster, Am Stadtgraben 9, 48143 Muenster, Germany (Gundel@insiwo.de).

I would like to thank an anonymous referee and the participants of the workshop in International Economics in Göttingen 2007 for helpful comments. Of course, all remaining errors are mine.

1 This list can be arbitrarily resumed with developing countries like China, India and Pakistan. But for sake of data reliability the analysis is concentrated on the CEECs, and here on PL, HU, CR. 
Central East European Countries - CEECs), has been playing a major role in the political and public discussion since the opening of these former communistic countries in the beginning of the nineties. The concerns regard mainly labour markets and thus future job security.

In times of globalization, the trade and capital movements increased considerably. The trade in goods and services grew faster than the GDP in the last twenty years and accordingly the degree of openness increases in almost every country that has opened up to free market economy. Particularly, the growth of the newly industrializing countries and developing countries is driven or at least accompanied by increasing exports. Thus, trade from these fast growing lower-wage countries has a considerable impact on industrial countries like Germany and poses a challenge for both firms and labour markets. The bulk of globalization impact and economic research refers to outsourcing and the structural change influencing the labour markets and the production process of the industrialized countries. The results are often not clear-cut because of the gains from trade if importing cheaper intermediate or consumer goods. Besides, in the theory of international trade the fear of industrial countries towards the fast growing newly industrializing countries and developing countries is based on the situation of biased growth and specialisation. If a new competitor imports and exports the same goods as the incumbent, the terms of trade can deteriorate due to increasing import prices and declining export prices or a loss of export market share (see Krugman, 1985, and Samuelson, 2004). The CEECs are not the cheap working bench of the industrialized countries any more but produce high-technology intensive goods which become more expensive. In this sense, they emerge as competitors of German exports in terms of cost and quality. Economic theory admits for decreasing terms of trade of the already industrialized country indicating a drawback to the autarky welfare level (see Samuelson, 2004). ${ }^{2}$ That is, in addition to outsourcing, the case since the CEECs have opened up to international trade quite rapidly after the breakdown of the closed system of communism, which was not based on concepts of comparative advantage. How Germany is facing this new environment can be seen regarding the competitiveness of the country. How is Germany performing in the international market of manufactured exports? What determines the export prices and how did they develop since the opening-up of the CEECs? Does the growth of the CEECs has an impact on Germany and is it negative or is the influence to small to show up in the data?

In search of answers, the development of export prices of manufactured goods are used to analyse the impact of increased competition on an already industrialized country and the potential net barter terms of trade loss due to a decline in export prices ceteris paribus. Goldstein and Khan $(1976,1985)$ and Hooper and Marquez (1995) contributed substantially to the topic of simultaneous export demand and supply equations. Most empirical work on foreign trade does not include the supply side of the markets in their

2 However, I concentrate in this analysis on the export side of the economy. The influence of a similar import structure and thus, combined with the impact on export prices the net barter terms of trade effect will not be covered in this paper. Also, I do not investigate the effect of "exporting deflation" by cheap manufactured goods like mentioned in the discussion of growth in China (see Rogoff, 2006). Since there are differences in tastes and thus demand influencing the trade flows I compare goods of comparable quality as offered by Germany and the CEECs. 
analysis. They assume the export price as exogenous due to infinite supply price elasticity (see also Goldstein and Khan (1985), p. 1087). Besides, Goldstein and Khan and Hooper and Marquez empirically estimated jointly determining the export supply income and price elasticities for imports and exports of several industrial countries. Sawyer and Sprinkle (1999) give a large overview of the empirical work on price and income elasticities for international trade. In the present paper the trade equations for manufactured exports are estimated using cointegration and error-correction estimation techniques according to Johansen (1991) and Johansen and Juselius (1994) in order to detect the long-term relationships. Similar proceedings for Germany are found in Clostermann (1996), Hooper, Johnson and Marquez (1998), Meurers (2004) and Strauß (2004) taking into account the latest issues that have come up in time-series econometrics (see Sawyer and Sprinkle (1999), p. 13 et sqq.). Besides, the above mentioned empirical work is more interested in the long-run income and price elasticity for exports but in the importance of intensified export competition. This part of the long-run relationship will be modelled in this paper by the market share of the CEECs in the observed export market of manufactured goods.

The remainder of this paper is structured as follows: The second chapter describes the structural change and the catch up process of the manufacturing industries and exports of the CEECs closing the technology gap. This can be seen from the stylized facts regarding the development of high-tech exports, market shares and export prices relative to Germany. In the third chapter the determinants of the export demand and supply in an imperfect substitute trade model will be specified. Following this, the empirical data are described. Chapter four explains the time series analysis prerequisites before applying the vector error correction model (VECM). After, the empirical results are presented. The paper closes with some concluding remarks.

\section{The CEECs as a New Competitor on Export Markets}

\subsection{Structural Change and Technology Catch-up Process}

The Europe Agreements ${ }^{3}$ of 1991, 1993 and 1995 and the opening up of the market were the starting point for liberalized and intensified trade and capital flows in Eastern Europe, in particular for PL, the CR and HU that joined the European Union on May 1, 2004.

During the transition period and thereafter, a large structural change in the composition of GDP took place. This process was characterized by de-agrarianization, de-industrialization and tertiarization (see Havlik, 2005, pp. 6-10 and more generally about the CEECs see also the Commission of the European Communities (2003) and the European Central Bank (2005)). Along with the sharp increase in trade volume and the structural change in the composition of GDP during 1993-2005, the trade pattern of the CEECs was accordingly rearranged as well.

In 1995, the exports of the CEECs were relative labour intensive due to the comparative advantage provoked by low labour costs. Table 1 shows the technology intensity of

3 Due to the Europe Agreements, the EU and the CEECs have phased out all statutory tariffs on industrial goods. 
manufactures exports from the CEECs and Germany. ${ }^{4}$ In 1995, the whole CEECs exported more not technology intensive products like apparel, iron, steel and metal products than technology intensive products. Besides, Germany already had its comparative advantage in high-tech manufactures ${ }^{5}$ exporting 67.8 per cent of total manufactures.

Table 1

Technology Intensity of Total World Manufactures Exports, CEECs and Germany, 1995, 2004

\begin{tabular}{|l|c|c|c|c|}
\hline \multicolumn{1}{|c|}{$\mathbf{1 9 9 5}$} & $\mathbf{C R}$ & HU & PL & GY \\
\hline High-technology manufactures & $4.1 \%$ & $10.1 \%$ & $4.2 \%$ & $15.4 \%$ \\
\hline Medium-high-technology manufactures & $37.0 \%$ & $32.8 \%$ & $24.6 \%$ & $52.4 \%$ \\
\hline High-tech & $41.1 \%$ & $42.9 \%$ & $28.7 \%$ & $67.8 \%$ \\
\hline Medium-low-technology manufactures & $31.9 \%$ & $19.8 \%$ & $31.7 \%$ & $16.0 \%$ \\
\hline Low-technology manufactures & $27.0 \%$ & $37.3 \%$ & $39.5 \%$ & $16.2 \%$ \\
\hline Low-tech & $58.9 \%$ & $57.1 \%$ & $71.3 \%$ & $32.2 \%$ \\
\hline \multicolumn{1}{|c|}{$\mathbf{2 0 0 4}$} & $\mathbf{C R}$ & HU & PL & GY \\
\hline High-technology manufactures & $16.2 \%$ & $34.8 \%$ & $6.2 \%$ & $20.2 \%$ \\
\hline Medium-high-technology manufactures & $44.4 \%$ & $39.6 \%$ & $38.2 \%$ & $51.3 \%$ \\
\hline High-tech & $60.6 \%$ & $74.4 \%$ & $44.4 \%$ & $71.5 \%$ \\
\hline Medium-low-technology manufactures & $22.9 \%$ & $11.2 \%$ & $27.3 \%$ & $15.3 \%$ \\
\hline Low-technology manufactures & $16.6 \%$ & $14.4 \%$ & $28.3 \%$ & $13.2 \%$ \\
\hline Low-tech & $39.4 \%$ & $25.6 \%$ & $55.6 \%$ & $28.5 \%$ \\
\hline
\end{tabular}

Note: Classification: High-technology: Aircraft and spacecraft; pharmaceuticals; office, accounting and computing machinery; radio, TV and communication equipment; medical, precision and optical instruments. Medium-high-technology: Electrical machinery and apparatus; motor vehicles, trailers and semi-trailers; chemicals excluding pharmaceuticals; railroad equipment and transport equipment; machinery and equipment. Medium-low-technology: Building and repairing of ships and boats; rubber and plastic products; coke, refined petroleum products and nuclear fuel; other non-metallic mineral products; basic metals and fabricated metal products. Low-technology: Manufacturing, Recycling; wood, pulp, paper, paper products, printing and publishing; food products, beverages and tobacco; textiles, textile products, leather and footwear.

Source: OECD, Bilateral Trade Database, own calculations.

Between 1995 and 2004, a restructuring of trade patterns in the CEECs towards more technology intensive branches took place. The high-tech exports of CEECs boosted and attained growth rates between lowest 524 per cent in PL and 798 per cent in HU compared to 182 per cent in Germany from 1995-2004. Nowadays, the structure is becoming similar to the one of the EU 15. The CEECs achieve competitiveness in technology intensive branches reflecting the economic characteristics of countries and commodities like in the Heckscher-Ohlin model (see similar in Havlik (2003), pp. 30-32). In 2004, all CEEC countries except PL exported more technology intensive products than non-technology intensive ones with HU ranking first (74.4 per cent). The strongest branches are automobile and parts, machinery and in the case of HU communication equipment. The underlying reasons for this catching-up are on various occasions. The

4 The author is aware of the problem stemming from aggregating manufactured products. Since the value chain for many products is broadly separated over industries and countries there is a classification problem. However, this problem can hardly be overcome, because the aggregation should stay arguable and the corresponding prices have to be available.

5 High-tech is defined as the sum of high-technology and medium-high technology. 
pattern of comparative advantage changes as relative factor endowments and available technology changes. According to the Rybczynski effects there is a biased expansion of production possibilities. In the CEEC case, relative factor supplies shift from land and labour towards capital and skills. Output expands in sectors that use relatively intensive capital whereas skills and output reduces in sectors that use relatively intensive other factors.

In this sense, the specialisation patterns of the CEECs in labour and resource intensive commodities and that of Germany in technology-intensive and capital-intensive products are melting off or are already melted off. The pattern of export structure is becoming similar. Especially regarding the strong export branches like machinery and automobile and parts the CEECs are reducing their comparative disadvantage or even reverse it. From the perspective of trade in manufactured goods, the CEECs have reached the level of industrialized countries (see similar in Havlik (2003), pp. 28-32).

\subsection{Market Share and Export Prices}

The technology catch-up process of the CEECs in manufactured goods evolves a new competitor for German exports in the common export market. ${ }^{6}$ The synthetic export market consists of 20 mainly OECD countries where data were available for. Since in this open $n$-country world, the relative prices of tradable goods are determined by the relative prices of the world market, Germany suffers downward pressure on its export prices due to increased competition from CEECs. In theory, Germany can either react by pricing to market (PTM) in order to keep the market share approximately constant or is loosing market shares. PTM forces a supplier to tie his export price to the competitor's one or to make price discrimination across markets (see Goldberg and Knetter (1997), pp. 1252-1268). The latter will not be followed up later. The supply of manufactured goods of the CEECs will increase in accordance with the profitability of producing and selling exports. Thus, the CEECs experience an export price increase due to higher demand and higher supply of more expensive and sophisticated goods. We can conclude that if the new competitor closes the technology gap towards the technology leader (in this case Germany) and has lower absolute factor prices, competition and augmented supply lead to downward pressure on the prices of the incumbents export goods. As a result, the export price of the advanced country can decline and the net barter terms of trade are ceteris paribus worse off. This could yield a welfare reduction by falling real income (see Krugman (1985), pp. 45-47). ${ }^{7}$

Figure 1 shows the development of the market share and export price of Germany and the CEECs in the period of 1993:1-2005:4 and confirms the strengthened competitiveness of the CEECs in the export market. The plot seems to follow theory explained

6 Besides, this effect is only one part of the changing trade pattern due to globalization. The other reflects the increased division of labour and accordingly production. Some fraction of trade between the market and the CEECs is taking place in the same industry (intra-industry trade) due to outsourcing of production parts from more advanced countries to the CEECs. This impact on the increased market share will be controlled for in the empirical analysis by the fraction of inward FDI in GDP of the CEECs.

7 The effects of changing terms of trade are not directly apparent when using net barter terms of trade. If you want to control for changes in productivity you have to use the double factorial terms of trade. 
above. The market share of the CEECs increased markedly throughout the period from 1.4 per cent to 4.6 per cent. The export price index of the CEECs increased considerably by 40.5 per cent experiencing the sharpest increase in the period from 1994:1-1999:4. For the rest of the time period the export price is quite stable while the market share is still growing. This empirical picture does not seem to be in line with the economic theory of strong export growth. In this case, a strong growing region is assumed to have declining export prices because the rest of the world can absorb the additional supply only via a decline in prices if the rest of world grows at a lower pace. But in the case of the CEECs the technological and quality catch-up process of manufactured exports enables a country to experience an increasing market share in combination with stable or increasing export prices. Germany is facing slightly falling export prices (-7 per cent) in accordance with quite unstable market shares during the period. But regarding the beginning and the end of the period it exhibits an almost unchanged market shares with 18 per cent in 1993:1 and 18.8 per cent in 2005:1. Regarding the interaction of these two variables, it shows growing market shares in connection with shrinking export prices in the period of 2000:3 to 2005:4. This gives some support for PTM and adjustment pressure stemming from intensified competition. ${ }^{8}$

Figure 1

Market Share and Export Price, Germany and CEECs, 1993-2005 (quarterly data)

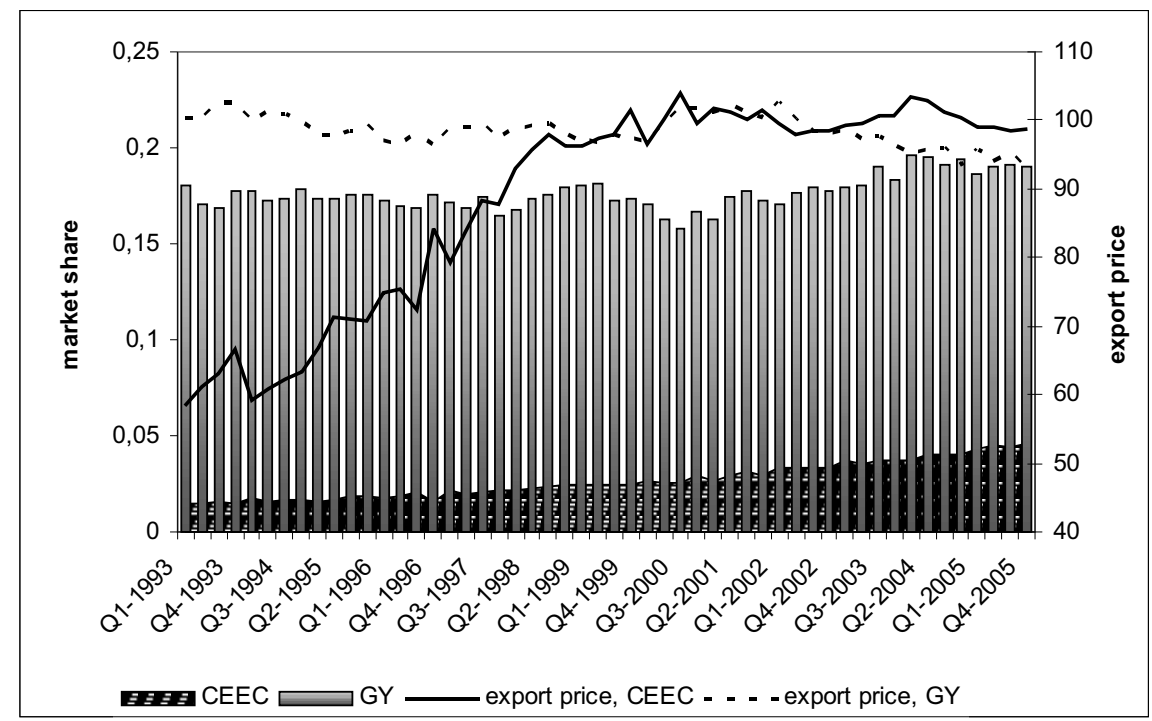

Note: Export price of GY is a unit value index of machinery and transport equipment in $€$. Export price of the CEECs is the mean of the export price index of machinery and transport equipment from CR, the unit value index of machinery and transport equipment from $\mathrm{HU}$ and of the unit value index of non-commodity goods and services exports from PL converted into $€$. The market shares are real exports ( $€$ ) of manufactured goods (SITC 5-8) of GY, the CEECs relative to the total exports of 20 OECD countries. See the data description in Appendix A1 for more details. Source: OECD, Monthly Statistics of International Trade, own calculations.

8 For sure, the export price is also determined by production costs. All other effects will be controlled for in the empirical analysis. 


\section{Determinants of Export Demand and Supply}

\subsection{Theoretical Concept}

In the $n$-country case, we perform an imperfect substitute trade model allowing for different exporters to charge different prices. The key reason for assuming an imperfect substitute model is the fact that Germany is heavily linked into intra-industry trade indicating that the exports and imports are not perfect substitutes. Intra-industry trade implies that countries are both exporters and importers of the same goods. ${ }^{9}$ Further, there are price differences for the "same" product in different countries (see Goldstein and Khan (1985), p. 1044). The assumption of an imperfect substitutes model instead of a perfect substitutes model follows the mainstay of empirical work on international trade (see Goldstein and Khan (1985), p. 1050 et sqq. and Sawyer and Sprinkle (1999), p. 5 et $s q q$.). The $n$-counties are represented by the 20 countries forming the synthetic export market.

The export demand function is specified in (1) as follows:

$$
\mathrm{EX}^{\mathrm{D}}=\mathrm{f}\left(\mathrm{Y}^{*}, \mathrm{P}_{\mathrm{EX}},\left(\mathrm{P}_{\mathrm{EX}}{ }^{*}+\mathrm{WEXR}\right)\right)
$$

where $\mathrm{EX}^{\mathrm{D}}$ : export demand

$\mathrm{Y}^{*}$ : import of manufactured goods from the export market

$\mathrm{P}_{\mathrm{EX}}$ : Export unit value index of manufactured goods

$\mathrm{P}_{\mathrm{EX}}{ }^{*}$ : Competitors (export market) trade weighted export unit value index of manufactured goods

WEXR: trade weighted nominal exchange rate

Since equation (1) is specified in logarithms you can easily interpret the coefficients as elasticities. Equation (1) is based on the following assumptions (see also Goldstein and Khan (1985), pp. 1045-1047, Goldstein and Khan (1978), p. 276, Stern, Francis and Schumacher (1976), pp. 4 et sqq. and Sawyer and Sprinkle (1999), pp. 8-11). First, export demand $\mathrm{EX}^{\mathrm{D}}$ of the observed country from the whole analysed market is negatively dependent on the export price $\mathrm{P}_{\mathrm{EX}}$, i.e. the price elasticity of demand is $\delta \mathrm{EX}^{\mathrm{D}} / \delta \mathrm{P}_{\mathrm{EX}}<0$. An increase in the price of an export good leads ceteris paribus, particularly at constant quality, to a decrease in demand. Second, the national price of an export good has always to be judged relative to competitive foreign suppliers because there is competition in the export market. A country's export faces not only competition from the importing sector of the trading partner. Exports from the third countries represented by the export market are sold to the importing country as well. Even, since in an $n$-country world, the dominant competition stems from exports of different countries rather than from the import competing domestic production like in the two-country case, the competitors export price $\left(\mathrm{P}_{\mathrm{EX}}{ }^{*}\right)$ captures the foreign substitutes effect. For the sake of a relative measure domestic and the foreign export price should be expressed in the same currency. Therefore the exchange rate (WEXR) is implemented in the export demand

9 In the case of the trade between the advanced countries and the CEECs, this will be controlled for in the econometric analysis by the FDI variable. 
function. Third, the exports of one country are the imports of the rest of the world. ${ }^{10}$ Thus, an increase in foreign imports of the analysed market $\mathrm{Y}^{*}$ leads to an increase of export demand. This follows from the consumption side of the GDP. A distinct fraction of the GDP will be consumed by imports. The advantage of using imports of the market instead of foreign GDP or foreign industrial production like in other related empirical and theoretical work is the possibility to compare the exports directly with the market volume and thus the relative development. If the elasticity of imports in export demand is unity, the observed home country has constant market shares, if $<1$, the country is loosing market share. This conclusion is feasible since most of the trade is taking part in between the analysed countries. Therefore an increase of imported manufactured goods coincides with an expansion of the export market. Turning now to the export price.

The variables of the export price function (2) are also specified in logarithms:

$$
\mathrm{P}_{\mathrm{EX}}=\mathrm{f}\left(\left(\mathrm{P}^{*}{ }_{\mathrm{EX}}+\mathrm{WEXR}\right), \mathrm{P}\right),
$$

where P: acronym for different national cost factors.

The determinants of the export price can be put into two categories. First, the domestic cost side and second the competitive world export market (see Goldstein and Khan (1978), p. 276, Goldstein and Khan (1985), p. 1047 et sqq., Hooper and Marquez (1995), p. 142 et sqq. and Möller and Jarchow (1990), p. 530 et sqq.).

The domestic cost side (P) can be represented by the producer price index (PPI) or by the unit labour costs (ULC). The price of imports represented by the price of imported intermediate goods or imported raw materials can also be considered, since the globalization enables firms to slice up their production chain and accordingly influences the cost side or a country is scarce of raw materials, respectively. Since these variables mirror the (factor) costs of the export production the export price is positively dependant on an increase of the domestic cost side. If the export price is given, the profitability to sell exports decreases when the production costs increase. In this sense, Bennstock and Minford (1976) classify a country as "price-transmitter" regarding the domestic side of price determination. Besides, a country is a "price-receiver" if the export price is predominantly set by competitors on world markets. In this sense, the higher the price elasticity of the export demand, the stronger the export prices depend on competitors export price $\mathrm{P}_{\mathrm{EX}}{ }^{*}$. However, in case of a low price elasticity of export demand the country's export products differ more from competitors products and are less substitutable as in case of a high elasticity. This refers to the PTM behaviour of exporters and their care about the price competitiveness of their exports and market shares as mentioned above.

Since Germany is a large and open country in economic sense both sides presumably play an important role. A large country usually has lower marginal production costs and lower demand price elasticity; i.e. the export prices are more driven by the domestic factor costs. On the other side, a large degree of openness to trade implies a high share of exports in total GDP and thus a larger impact of competitors export prices (see Goldstein and Khan (1985), p. 1091 et sqq.).

10 Here, the rest of the world is captured by the analysed market. This is possible since the bulk of trade is taking place between the analysed industrial countries. 
From a modelling perspective we have to mention that $\mathrm{P}_{\mathrm{EX}}$ in equation (1) is an endogenous explanatory variable because it is jointly determined in equation (2) of the same economic model (see Goldstein and Khan (1985), p. 1071). Equation (1) and (2) are a simultaneous equation system and we are facing the problem of simultaneity bias, respectively (see Greene (2003), p. 379). Any change in the price of exports resulting from equation (2) has an impact on the quantity of exports via the export price elasticity of demand. This problem is overcome using the Johansen procedure (1991) which allows for several potential endogenous variables in the system. Former empirical work applied Two-Stage Least-Squares method (see Goldstein and Khan (1985) and Hooper and Marquez (1995), Möller and Jarchow (1990)) and Full Information Maximum Likelihood method (see Goldstein and Khan (1978)).

\subsection{Data}

The data are time series from the OECD Monthly Statistics of International Trade and Main Economic Indicators. The observation period extends from 1993 to 2005 using quarterly data, respectively. Unfortunately, earlier data were not available without losing plenty of information and consistency especially concerning the CEECs. Besides this shortcoming for the estimation procedure, this period corresponds with the era of structural change and opening up in the CEECs and with Germany after reunification adjustments. As usual for that kind of analysis, all variables included in the estimations are logarithms. The export market is defined by 17 industrial countries for which data were available and the CEECs. This refers to Germany, PL, HU, the Czech Republic, Australia, Canada, Switzerland, Denmark, Spain, Finland, France, the United Kingdom, Ireland, Italy, Japan, Korea, Norway, New Zealand, Sweden, and the United States. For the export prices of Germany and the competitors export unit value indices (base year: 2000) are used. For the import price the price index of imported raw material (base year: 2000) is used. For the producer price index of the German manufacturing industry an index based in 2000 is used, the same for the unit labour cost index of the manufacturing industry, respectively. The competitors price is a trade weighted index using the export market shares of the OECD countries as weights. The competitors export price is converted into the domestic currency $(€)$ by the weighted nominal effective exchange rate (domestic currency relative to foreign currency). The weights are the same as described above. For Germany, machinery and transport equipment unit values were used as a proxy for the export price of manufactured goods. In the case of the competitors price, the machinery and transport equipment unit value indexes were used for most countries as well. Due to data availability the export unit value of machinery and transport equipment was substituted for some countries by the export unit value of manufactured goods. The German exports are aggregated exports from the Standard International Trade Classification (SITC 5-8) measured in f.o.b. values in billions of USD converted into $€$. The activity parameter in the export demand equation are the SITC 5 to 8 imports from all observed OECD countries without Germany measured in billions of USD converted into $€$. The exports and the imports are real values since they are deflated with the equivalent change of the underlying price indices. The nominal effective exchange rate index (base year: 2000) (wexr) is the trade weighted relation of the domestic currency $(€)$ relative to the national currencies of the 
export market countries. The foreign variables (exchange rate and prices) are weighted averages according to their real export shares across the countries included in the export market not including the home country Germany. In the econometric model, the variable $\mathrm{ms}$ is added to capture the competition effect on the German export price stemming from the technological catch-up process and market share gain of the CEECs. The variable is constructed as the share of SITC 5-8 exports from CEECs in total SITC 5-8 exports including Germany. The variable is transformed into an index (base year: 2000) and calculated as logarithm.

The conversion of the competitors export value index into $€$ ensures that all price variables (domestic and foreign) are expressed in the same currency $(€)$. The nominal effective exchange rate enters the analysis indirectly through the conversion of foreign prices, the combined variable competitors export unit value index of machinery and transport equipment in national currency, respectively. The main reason for using a combined variable is the advantage of complexity reduction of the system from seven to six variables which yields better estimation results with respect to the small sample size. An overview over all variables used in the estimation is given in Appendix A1.

\section{Empirical Model}

The econometric methodology employed in this paper uses Johansen's cointegration methodology to identify the long-run relationship among the trade variables of the system. This is suitable because the long-term equilibrium should correspond with the economic theory outlined before and due to the endogeneity of some variables. But before estimating the VECM the stochastic properties of the data are analysed by unit root tests in order to avoid the problem of spurious regression.

\subsection{Unit Root and Cointegration}

The trending behaviour of the time series is important in order to specify the economic model correctly and imply cointegration relationships in levels. I use the Augmented Dickey Fuller test (ADF) for testing for unit roots. The results are summarized in Table 2. Before performing this test, it is important to specify the deterministic components (time trend, intercept) of the variables. Like for most macroeconomic time series (see Perron (1988), p. 304) a deterministic trend is incorporated into all regression equations except the one for the wexr and the competitors export price (pex_comp). In the case of the increase of exports and imports, the producer price and the market share of the CEECs economic judgement gives support for a deterministic trending behaviour (see similar considerations in Strauß (2004), p. 52 et sqq.). 
Table 2

Unit Root Tests

\begin{tabular}{|c|c|c|c|c|c|}
\hline \multirow{3}{*}{ Time series } & \multirow{3}{*}{ Lags } & \multicolumn{3}{|c|}{ ADF } & \multirow{3}{*}{$\begin{array}{l}\text { Integration } \\
\text { grade }\end{array}$} \\
\hline & & \multicolumn{2}{|c|}{ For levels } & \multirow{2}{*}{$\begin{array}{c}\text { For 1st differences } \\
\text { i }\end{array}$} & \\
\hline & & $\mathbf{i}$ & $\mathbf{i}, \mathbf{t}$ & & \\
\hline Ex & 4 & -0.964230 & -2.698173 & $-3.357574 * *$ & $\mathrm{I}(1)$ \\
\hline wexr & 0 & -1.408194 & -1.358849 & $-6.295524 * * *$ & $\mathrm{I}(1)$ \\
\hline $\mathrm{ms}$ & 0 & 0.740433 & $-8.800318 * * *$ & $-11.68048 * * *$ & $\mathrm{I}(0)$ \\
\hline pex_comp & 1 & -1.631616 & -1493348 & $-5.319528 * * *$ & $\mathrm{I}(1)$ \\
\hline pex_eu & 3 & -1.564617 & $-3.269780^{*}$ & $-6.251798 * * *$ & $\mathrm{I}(1)$ \\
\hline pex & 0 & -1.668156 & -2.272036 & $-9.006679 * * *$ & $\mathrm{I}(1)$ \\
\hline $\mathrm{y}$ & 5 & -1.095451 & -1.977652 & $-3.426326^{* *}$ & $\mathrm{I}(1)$ \\
\hline ppi & 1 & 0.419365 & -2.060454 & $-3.783418 * * *$ & $\mathrm{I}(1)$ \\
\hline pim & 3 & -0.613420 & $-3.881714 * *$ & $-4.204181 * * *$ & $\mathrm{I}(0)$ \\
\hline ulc & 2 & 0.835118 & -1.412319 & $-4.352144 * * *$ & $\mathrm{I}(1)$ \\
\hline
\end{tabular}

Note: ${ }^{* * *},{ }^{* *}$ and * significant at the 1\%-, 5\%- and 10\%-level. The included lags are based on Schwarz Information Criterion (SIC) in a model with a trend and intercept. The lag length was restricted to $p=4$ in order to improve the power of the test following the procedure proposed by Said and Dickey (1984). $\mathrm{i}=$ intercept, $\mathrm{t}=\mathrm{trend}$.

The number of lags (p) in the system using a model with intercept and trend is selected by the Schwarz Information Criteria (SIC) in such a way that the residuals are not autocorrelated. The result can be seen in the second column of Table 2. For the unit root test in levels only the variable ms and pim are stationary, thus $\mathrm{I}(0)$, if using a trend and an intercept, i.e. they are trend-stationary. ${ }^{11}$ For all other variables, the null hypothesis of a unit root is not rejected. Proceeding with testing for a second unit root, the null hypothesis of a unit root in first differences can be clearly rejected (at a significance level of at least $5 \%$ ) for ex, wexr, pex_comp, pex_eu, pex, y, ppi and ulc. Thus, all variables included in the system are integrated of order one (I(1)) except ms and pim. The latter is excluded from the model specification due to that shortcoming using cointegration. The regression equations for the first differences were specified without a linear trend, since I(1) is assumed.

In a system of I(1) variables the variables are called cointegrated if there exists a linear combination between I(1) that is stationary (see for example Johansen (1992b), p. 313). Before estimating the long-run relationships of the system, some preliminary specifications have to be done (see Harris (1995), pp. 76-96). The deterministic specification and the lag length of the system influence the estimation results and have to be determined. As in the case of the unit root testing procedure, visual inspection and economic reasoning give support for assuming a model with an intercept and a deterministic trend restricted to the cointegration space in the time series. In trade equation systems, the trending behaviour can be interpreted as the increasing impact of globalization being equivalent to a long-run linear trend, i.e. trade liberalization, division of labour and falling transaction and transportation costs. The intercept accounts for units of measurement. The optimal lag structure was determined using an unrestricted VAR. Calculating Hannan-Quinn information criterion (HQIC) and

11 The trend was significant in both ADF-tests. Yet leaving the trend out the null could be clearly rejected. 
sequential modified likelihood ratio tests, I choose a lag length of three in levels based on the model with trend and intercept in order to ensure that the residuals are free from autocorrelation, non-normality etc. ${ }^{12}$ Additional to the information criteria the autocorrelation ML test reports no residual serial correlation at a lag length of three as well. White heteroskedasticity test clearly rejects the null of heteroskedastic residuals.

The number of cointegration relations was specified employing the Johansen procedure as described in Johansen (1991) and Johansen and Juselius (1994). Which kind of deterministic component should finally be applied and how many cointegration vectors are accepted in the system is determined jointly following the Pantula principle proposed in Johansen (1992a) and Pantula (1989) (see also Harris (1995), p. 97). The results are shown in Table 3. The so called Pantula principle starts with the most restrictive model (Model 1 and $\mathrm{r}=0$ ) and moves over the next restrictive model (Model 2) to the least restrictive one (Model 3). Meanwhile, the trace or max-eigenvalue statistics is regarded till the null hypothesis is not rejected for the first time. Accordingly, starting with the value of 227.95 or 74.88 , respectively and moving through the rows the procedure stops at 44.64 or 32.10. We can determine the time series having a linear deterministic trend and at least $\mathrm{r}=2$ cointegrating relations. But depending on the significance level the max-eigenvalue statistics identifies $r=3$ cointegrating relations as does the trace statistic at the 5 per cent level. Since the stationary variable $\mathrm{ms}$ is included in the procedure, there exists automatically one cointegrating relation and we justify three cointegration relationships. The trend-stationary variable ms forms a cointegrating relation by itself (see Harris (1995), p. 80). ${ }^{13}$

Table 3

Johansen Test for the Number of Cointegrating Relations

\begin{tabular}{|c|c|c|c|c|c|c|}
\hline \multirow{3}{*}{$\begin{array}{c}\mathbf{r} \\
\text { under } \\
\text { H0 }\end{array}$} & \multicolumn{3}{|c|}{ Trace statistic } & \multicolumn{3}{|c|}{ Max-eigenvalue statistic } \\
\hline & Model 1 & Model 2 & Model 3 & Model 1 & Model 2 & Model 3 \\
\hline & $\begin{array}{l}\text { No deterministic } \\
\text { trend (restricted } \\
\text { constant) }\end{array}$ & $\begin{array}{c}\text { Linear } \\
\text { deterministic } \\
\text { trend }\end{array}$ & $\begin{array}{c}\text { Linear } \\
\text { deterministic } \\
\text { trend } \\
\text { (restricted) } \\
\end{array}$ & $\begin{array}{l}\text { No deterministic } \\
\text { trend (restricted } \\
\text { constant) }\end{array}$ & $\begin{array}{c}\text { Linear } \\
\text { deterministic } \\
\text { trend }\end{array}$ & $\begin{array}{c}\text { Linear } \\
\text { deterministic } \\
\text { trend } \\
\text { (restricted) }\end{array}$ \\
\hline $\mathbf{0}$ & $227.95 * * *$ & $192.73 * * *$ & $229.72 * * *$ & $74.88 * * *$ & $70.98 * * *$ & $70.99 * * *$ \\
\hline 1 & $153.07 * * *$ & $121.75 * * *$ & $158.73 * * *$ & $45.03 * *$ & $45.01 * *$ & $51.28 * * *$ \\
\hline 2 & $108.05 * * *$ & $76.74 * *$ & $107.45^{* * *}$ & $39.08 * *$ & $32.11 *$ & $35.66^{*}$ \\
\hline 3 & $68.96 * * *$ & $44.64 *$ & $71.79 * * *$ & $29.37 * *$ & 21.93 & $31.08^{*}$ \\
\hline 4 & $39.59 * *$ & 22.71 & $40.71 *$ & $20.64 *$ & 14.42 & 19.19 \\
\hline 5 & $18.95 *$ & 8.29 & 21.52 & 10.81 & 8.18 & 13.75 \\
\hline 6 & 8.14 & 0.11 & 7.76 & $8.14 *$ & 0.11 & 7.76 \\
\hline
\end{tabular}

Note: ${ }^{* * *},{ }^{* *}$ and * significant at the 1\%-, 5\%- and 10\%-level. Critical values from MacKinnon-Haug-Michelis (1999). The deterministic trend models follow the considerations of Johansen (1995). In Model, there are no

12 The Akaike Information Criterion (AIC) voted for a lag length of 4, the SIC for two lags.

13 The variables of the model have also been tested for cointegration without the $\mathrm{I}(0)$ variable $\mathrm{ms}$ in order to exclude the case of building $\mathrm{ms}$ the three identified cointegrating relationships with different $\mathrm{I}(1)$ variables in the system. These tests justified $\mathrm{r}=3$ according to the trace and $\mathrm{r}=2$ according to the max-eigenvalue statistics each at the 5 and $10 \%$ significance level. Here we would decide for $r=2$ and not for $r=3$ because the economic reasoning does not give support for a third cointegration relationship. 
trends, but a constant term is allowed in the co-integrating relations. Model 2 allows for a linear trend in each variable but the co-integrating relations only have intercepts. In Model 3, there are linear trends allowed in all components of the process (see Johansen (1995), pp. 80-83). The box indicates the first time when the null hypothesis is not rejected.

\subsection{Model Specification}

Given the non-stationarity of the variables and the existence of $r$ cointegration vectors, the trade model is estimated in a VECM. I follow the procedure developed by Johansen (1991) and Johansen and Juselius (1994). Performing this approach long-run relations, i.e. cointegration relations, and short-run adjustments can be verified and distinguished. For the analysis the following unrestricted VECM is assumed:

$$
\Delta \mathrm{Z}_{\mathrm{t}}=\prod * \mathrm{Z}_{\mathrm{t}-1}+\sum_{i=1}^{k-1} \Gamma_{\mathrm{i}}^{*} \Delta \mathrm{Z}_{\mathrm{t}-\mathrm{i}}+\mu+\varepsilon_{\mathrm{t}},
$$

where $Z_{t}$ represents a $(n \times 1)$ vector of the $n$ endogenous variables $\left(Z_{t}=\left[Z_{t, 1} \ldots Z_{t, n}\right]\right)$ with $\mathrm{t}=1993: 1, \ldots, 2005: 4 . \varepsilon_{\mathrm{t}}$ denotes a $(\mathrm{n} \times 1)$ vector of iid residuals and $\mu$ the $(\mathrm{n} \times 1)$ vector of constants and $\Delta$ a difference operator. If the time-series are I(1) and there are $r$ cointegrating relations in the variables $Z_{t}$, the $(n \times n)$ matrix $\Pi$ has to be of reduced rank $(0<\mathrm{r}<\mathrm{n})$, i.e. $\Pi=\alpha \beta^{\prime}$, where $\alpha$ and $\beta$ are (nx r)-dimensional matrices. The cointegration vector $\beta^{\prime}$ represents the long-run cointegrating relations, whereas $\alpha$ denotes the speed of adjustment moving to the long-run equilibrium. $\alpha$ is known as a loading coefficient. The ( $\mathrm{n} \times(\mathrm{k}-1))$ matrix $\Gamma_{\mathrm{i}}$ represents the short run coefficients, where $\mathrm{k}$ is the lag order.

For the structural specification of the export system, the starting point is a VECM with lag length $\mathrm{k}=3$ and $\mathrm{n}=6$ endogenous variables, namely ex, pex, pex_comp+wexr, ulc, ms and $\mathrm{y}$. In the reduced rank $\Pi$ we interpret the $\mathrm{r}=2$ cointegration relations according to the theory as structural long-run relationships of export demand, and supply. Thus, the dependent variables are the exports (ex) and the national export price (pex). ${ }^{14}$ Following the theoretical remarks above, the first cointegration relation is labelled demand (1) and the second supply (2). Accordingly, the cointegration relation has been normalized on the exports and on the export price. Zero restrictions are imposed on the variables ulc in (1) and on y in (2) since they do not have an impact in the structural relationship. The restriction of the just-identified model implies that a change in ulc does not have a direct long-run impact on export demand. For the demand, the export price and the price on world markets is determining. Besides, there can still be short-run effects and surely indirect domestic cost-price effects of ulc via the export price. Therefore, the variables in the demand vector are y, pex and (pex_comp+wexr) and ms. Accordingly for (2), y has no direct influence on the long-run export price. Consequently, the supply vector of the just-identified model can be described by the predetermined variables ex, (pex_comp+wexr), ulc and ms. The validity of the restriction is tested with a classical $\chi^{2}$-distributed likelihood ratio test according to Johansen and Juselius (1992).

14 In order to check for causality a Granger analysis was performed supporting the theoretically expected causation. I could not reject the hypothesis that pex, pex_comp and y Granger cause ex and that ex, pex_comp, ulc, ppi and ms Granger cause pex. 
The just-identified long-run structure of the export system was tested by several hypotheses imposing some overidentifying restrictions using classical likelihood ratio tests. ${ }^{15}$ The goal is exact identification motivated by economic arguments. First the hypothesis of a long-run export supply that is infinitely price elastic was tested imposing the restriction $\beta_{2, \mathrm{ex}}=0$, where the number in the index denotes the cointegration relation (1: demand, 2: supply) and the variable is the parameter under restriction. Although this assumption is often made in the literature, it was rejected here. Another supply side hypothesis of interest is whether Germany is a price transmitter and thus insulated from the competitors price $\left(\beta_{2 \text {,pex_comp }}=0\right)$. As supposed from economic intuition this hypothesis was rejected as well. The interesting question whether the influence of the CEECs is to small to have an impact on Germanys export system is tested via the restriction $\beta_{1, \mathrm{~ms}}=\beta_{2, \mathrm{~ms}}=0$. We can reject the hypothesis of no influence stemming from the CEECs to Germany. Besides the hypothesis of no impact of the CEECs on the export demand $\left(\beta_{1, \mathrm{~ms}}=0\right)$ could not be rejected. One reason might be that adjustment to the intensified competition goes via the export price.

Imposing zero restrictions on the loading coefficients leads to the question of weak exogeneity. That means the error correction term does not play a role in adjusting to the disequilibrium changes of the cointegration vector under consideration (see Johansen (1992b). Again likelihood ratio tests, as described for example in Harris (1995) and Johansen (1992b), showed that pex_comp can be treated as weakly exogenous. For all other variables, the null of weakly exogeneity can be clearly rejected giving support for the assumed cointegrating relations in the case of pex and ex. Regarding the weakly exogeneity restriction of pex_comp we formulate the loading coefficient $\alpha_{\text {pex_comp, } 1}=\alpha_{\text {pex_comp }, 2}=0$.

\subsection{Empirical Results}

The results of the VECM estimation are summarized in Table 4. Eight different models have been regressed in order to check the robustness of the results. Due to the small sample problems of the VECM the estimation results were further ensured by a FIML estimation yielding similar results especially regarding the sign and therefore the economic intuition.

In order to check the robustness of the estimation the exogenous variable $g$ was introduced in the model (3), (4), (6), (7) and (8). The variable $g$ is a proxy for globalization capturing the fact that exports and imports grow stronger than GDP. The variable is calculated as the share of exports in GDP of the whole market. But including this variable yields a serious problem. The loading coefficient of the export demand equation does not show the theoretically required characteristics $(-1<\alpha<0)$ and brings up some interpretation problems. The variable FDI is included in the model (2), (4) and (7) in order to control for the fraction of increased market share of the CEECs stemming from amplified trade in intermediates and thus non-competition effect. The share of FDI in GDP is used as a proxy for this part of trade between advanced countries and newly industrializing countries caused by increased outsourcing activities of manufacturing

15 The LR tests of the hypothesis are summarized in Table A 2 in the Appendix. 
industries. Besides, the variable FDI is never significant in the export supply equation and the estimation results are quite stable compared to the models without FDI. In model (5) - (7) the restriction $\beta_{2, \mathrm{~ms}}=0$ is loosed because the LR results are on the border of significance. Regarding the models (1) to (8) we can conclude that the models all show the expected negative sign for the main variable of interest ms. After interpretation of the different specifications, the test statistics and the theoretical requirements mentioned above model (1) is the preferred reference one.

Table 4

Estimation Results of Long-Run Export Demand and Supply

\begin{tabular}{|c|c|c|c|c|c|c|c|c|}
\hline Model & (1) & (2) & (3) & (4) & (5) & (6) & (7) & (8) \\
\hline Export demand [1] & \multicolumn{8}{|c|}{ Cointegration coefficients } \\
\hline ex & 1 & 1 & 1 & 1 & 1 & 1 & 1 & 1 \\
\hline pex & $3.30 *$ & $3.32 *$ & $0.97 *$ & $0.97 *$ & 0.14 & $0.95 *$ & $0.96^{*}$ & $0.91 *$ \\
\hline pex_comp & -0.47 & -0.42 & $-0.99 *$ & $-0.99 *$ & $0.50 *$ & $-0.98 *$ & $-0.98 *$ & $-1.33^{*}$ \\
\hline $\mathrm{y}$ & $-0.64 *$ & $-0.63 *$ & -0.04 & -0.05 & $-0.42 *$ & -0.05 & -0.05 & $0.14 *$ \\
\hline $\mathrm{ms}$ & - & - & - & - & $-0.45^{*}$ & -0.01 & -0.00 & - \\
\hline Export supply [2] & \multicolumn{8}{|c|}{ Cointegration coefficients } \\
\hline pex & 1 & 1 & 1 & 1 & 1 & 1 & 1 & 1 \\
\hline ex & $-0.44^{*}$ & $-0.45^{*}$ & $0.61 *$ & $0.55^{*}$ & $-0.66^{*}$ & $0.61 *$ & $0.55^{*}$ & $-2.92 *$ \\
\hline pex_comp & $-0.67 *$ & $-0.67 *$ & $-1.07 *$ & $-1.07 *$ & $-0.89 *$ & $-1.07 *$ & $-1.07 *$ & $1.48^{*}$ \\
\hline ulc & $0.78^{*}$ & $0.81 *$ & $0.32 *$ & $0.37 *$ & $1.44 *$ & $0.33 *$ & $0.39 *$ & - \\
\hline ppi & - & - & - & - & - & - & - & $1.49^{*}$ \\
\hline $\mathrm{ms}$ & $0.52 *$ & $0.53 *$ & $0.20^{*}$ & $0.23 *$ & $0.76^{*}$ & $0.21 *$ & $0.24 *$ & $0.27 *$ \\
\hline fdi & - & 0.00 & - & 0.00 & - & - & 0.00 & - \\
\hline $\mathrm{g}$ & - & - & $0.14 *$ & $0.14 *$ & - & $0.14 *$ & $0.14 *$ & $0.12 *$ \\
\hline Loading coefficient [1] & $-0.16^{*}$ & -0.12 & $-1.59 *$ & $-1.44 *$ & $-0.52 *$ & $-1.54 *$ & $-1.40 *$ & $1.08^{*}$ \\
\hline \multirow[t]{2}{*}{ Loading coefficient [2] } & $-0.28 *$ & $-0.28 *$ & $-0.85^{*}$ & $-0.72 *$ & $-0.21 *$ & $-0.81 *$ & $-0.70 *$ & $-0.34 *$ \\
\hline & \multicolumn{8}{|c|}{ Test statistics } \\
\hline $\mathrm{X}^{2}$-LR-test (df) & $7.43(3)$ & $5.79(3)$ & $2.55(3)$ & $1.46(3)$ & $2.71(2)$ & $2.56(2)$ & $1.46(2)$ & $7.49(3)$ \\
\hline Adjusted R $\_$[1] & 0.77 & 0.77 & 0.79 & 0.79 & 0.78 & 0.79 & 0.79 & 0.83 \\
\hline 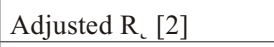 & 0.41 & 0.40 & 0.45 & 0.44 & 0.37 & 0.45 & 0.44 & 0.46 \\
\hline AIC & -31.26 & -31.18 & -31.81 & -31.73 & -31.36 & -31.81 & -31.73 & -30.10 \\
\hline SIC & -27.33 & -27.02 & -27.64 & -27.32 & -27.42 & -27.64 & -27.32 & -25.93 \\
\hline
\end{tabular}

Note: * significant at the $5 \%$-level.

It shows a stable long-run relationship for the export demand. The price elasticity of demand is very high $(-3.30)$ and highly significant. This result is kind of surprising although the price elasticity for manufactured goods is higher than for aggregate exports or nonmanufactures (see Goldstein and Khan (1985), p. 1070). Besides it fits into the assumption of intensified competition and higher substitutability of German exports. The foreign price elasticity has the expected sign but is insignificant. The coefficient of the activity variable is $<1(0.64)$ and highly significant. This means that a one per cent increase in the imports of manufactured goods in the observed market leads to a less strong increase in demand of German goods. This indicates a loss of market share in 
the long-run. For the export price function we also obtain a stable long-run relationship with all coefficients being significant. But regarding the ulc the sign does not match theory. An increase in the unit labour cost index leads to a decrease in the export price. ${ }^{16}$ The competitors export price exhibits the expected sign. The value of 0.67 means that a one per cent price increase in the market is not fully shifted into German export prices. One interpretation may be the competition stemming from new entrants in the market of manufactured goods. Since the competitors catch up in quality a price increase of their goods cannot completely be followed by German firms if they want to stay competitive. This is also represented in the negative coefficient of the market share of the CEECs. An increasing market share results in a pressure on German export prices. ${ }^{17}$

The loading coefficients show the direction and speed of adjustment of an endogenous variable when there is an export supply or demand disequilibrium. ${ }^{18}$ For the export demand equation, we estimate a loading coefficient $(-0.16)$ that is at the border of five per cent significance level and shows the theoretically required sign. An excess demand is stabilized by a falling demand, rising market share of the CEECs and decreasing imports from the market. This result is consistent with economic theory. For the export price adjustment coefficient on the export demand cointegration equation, theory expects a positive sign, since rising prices correct the excess demand. But the corresponding adjustment coefficient of the estimation is insignificant. One reason might be sticky prices.

Since the export price equation is of particular interest in this analysis the whole equation results including the short-run dynamic are formulated in (4) showing only the significant parameters for parsimonious reasons ( $t$-values in parenthesis).

$$
\begin{gathered}
\Delta \text { pex }=-0.28 *\left[\text { pex }_{-1}-0.44 * \mathrm{ex}_{-1}-0.67 * \mathrm{pex}_{-} \mathrm{comp}_{-1}+0.78 * \mathrm{ulc}_{-1}+0.52 * \mathrm{~ms}_{-1}+3.19\right]- \\
(-3.85) \\
(-5.37)
\end{gathered}
$$

$$
\begin{array}{cccc}
0.46 * \Delta \mathrm{pex}_{-1}-0.24 * \Delta \mathrm{pex}_{-2}-0.19 * \Delta \mathrm{ex}_{-1}-0.11 * \Delta \mathrm{ex}_{-2}-1.07 * \Delta \mathrm{ulc}_{-2} \\
(-2.95) & (-1.66) & (-2.53) & (-1.89)
\end{array}
$$

Test statistics: LM (1): 30.80 (0.72); LM (4): 29.48 (0.77); Jarque-Bera: 2.62 (0.27); White test: $8.54(0.36)$

The error correction term of the export price equation is -0.28 and highly significant. Thus, the adjustment to the long-run cointegration relationship described above is faster than for the export demand disequilibrium adjusting 28 per cent of the export price within one quarter. The correction of a supply disequilibrium taking the form of an export price above the long-run level goes via falling prices, falling ulc and

16 For the VECM, several specifications with different sets of cost/price variables already mentioned in the theoretical model have been tested. The ppi behaves similar to the ulc (see model (8)), while the pim was not used for the VECM due to its I(0) property.

17 The export system was additionally estimated using FIML yielding similar results. This shows the robustness of the negative sign of the ms variable and the $<1$ property of the income elasticity of export demand.

18 The loading coefficients of model (1) are summarized in Table A 3 in the Appendix. 
rising volumes. This is in line with economic theory. The effect on market share and the imports is not interpretable in an economically reasonable manner. The short-run part became very parsimonious because of the exclusion of insignificant parameters. The dynamics of the lagged periods exhibits jointly declining export prices and exports.

\section{Conclusion}

The CEECs experienced a considerable change in their industries and competitiveness since they abolished communism and opened up to trade. A technological catch-up process took place especially in the manufacturing industry changing the specialisation and thus the export pattern caused by new technologies, FDI flows and higher educational attainment. Accordingly, medium- to high-tech exports of already industrialized countries are exposed to the competition stemming from newly industrializing countries offering the same goods in the same markets. This describes the situation of Germany suffering falling export prices in the period of 1993-2005. The assumed competition effect of the CEECs on German export prices became evident applying VECM on manufactured export demand and supply. The competition elasticity of export prices is negative. This means that a one per cent increase of the market share of the CEECs reduces the export price of German manufactured products by 0.52 per cent in the long-run and thus forces German firms to sell goods more cheaply on world markets. Irrespective of any German market share movements this is reducing the welfare effect of selling exports if the import price does not decrease at the same rate. This terms of trade effect is interesting to be analysed in the future, yet requires an amplified data set in order to improve the estimation results. But to significantly influence the income of a - though open - large country the terms of trade decline has to be considerable. Further, such an analysis requires accounting for the total effect of the income terms of trade.

Another caveat alongside the small sample size is the rough trade aggregation. A deeper aggregation enables to distinguish more clearly between increased market share of the CEECs due to outsourcing or competition effect than does the variable FDI used in this analysis. Data availability for the observed countries especially regarding the corresponding export price variables are the shortcoming for this improvement.

Since the CEECs are well integrated into the international division of labour and the institutional arrangements becoming more efficient being member of the European Monetary Union the process of producing more sophisticated products will be aggravated, particularly in terms of quality. A possible way to insulate Germany from lower cost competition should be to concentrate more on high-technology and innovative products. The fear of decreasing welfare in Germany has no reason if the specialisation pattern moves according to comparative advantages and Germany allows for outsourcing and offshoring the less competitive industries or steps within a value chain. The forthcoming entry of the CEECs into the European Monetary Union brings up some challenges for Europe due to intensified trade, yet also opportunities to import cheaper intermediate products. Other East European and Asian countries head for the development of the CEECs in a few years. Thus, the changing pattern of specialisation 
never stops and becomes a huge challenge for both, highly developed countries and firms. The ability to adjust will be one of the crucial determinants of competitiveness and ensures the gains from trade.

\section{References}

Bennstock, M., Minford, P. (1976), "A Quarterly Econometric Model of World Prices, 1955-71", in Parkin, M., Zis, G., ed., Inflation in Open Economies. Manchester.

Clostermann, J. (1996), "Der Einfluß des Wechselkurses auf die deutsche Handelsbilanz". Discussion Paper No. 7/96, Economic research group of the Deutsche Bundesbank.

Commission of the European Communities (2003), "Impact of Enlargement on Industry". Commission Staff Working Paper, SEC 234, Brussels.

European Central Bank (2005), "Competitiveness and the Export Performance of the Euro Area". Occasional Paper Series, No. 30.

Goldberg, P., Knetter, M. (1997), "Goods Prices and Exchange Rates: What Have We Learned?" Journal of Economic Literature, 35, pp. 1243-1272.

Goldstein, M., Khan, M. S. (1978), "The Supply and Demand for Exports: A Simultaneous Approach". The Review of Economics and Statistics, 60, pp. 275-286.

Goldstein, M., Khan, M. S. (1985), "Income and Price Effects in Foreign Trade”, in Jones, R. W., Kenen, P. B., ed., Handbook of International Economics, Vol. II. Amsterdam.

Greene, W. H. (2003), Econometric Analysis. $5^{\text {th }}$ ed. New Jersey.

Harris, R. (1995), Using Cointegration Analysis in Econometric Modelling. London : Prentice Hall.

Havlík, P. (2003), "Restructuring of Manufacturing Industry in the Central and East European Countries". Prague Economic Papers, 12 (1), pp. 19-36.

Havlík, P. (2005), "Structural Change, Productivity and Employment in the New EU Member States". WIIW Research Reports, No. 313.

Hooper, P., Marquez, J. (1995), "Exchange Rates, Prices, and External Adjustment in the United States and Japan", in Kenen, P. B., ed., Understanding Interdependence. Princeton.

Hooper, P., Johnson, K., Marquez, J. (1998), "Trade Elasticities for G-7 Countries, Board of Governors of the Federal Reserve System". International Finance Discussion Papers, No. 609.

Johansen, S. (1991), "Estimation and Hypothesis Testing of Cointegration Vectors in Gaussian Vector Autoregressive Models". Econometrica, 59 (6), pp. 1551-1580.

Johansen, S. (1992a), "Determination of Cointegration Rank in the Presence of a Linear Trend". Oxford Bulletin of Economics and Statistics, 54 (3), pp. 383-397.

Johansen, S. (1992b), "Testing Weak Exogeneity and the Order of Cointegration in UK Money Demand Data". Journal of Policy Modeling, 14 (3), pp. 313-334.

Johansen, S., Juselius, K. (1994), "Identification of the Long-Run and the Short-Run Structure. An Application to the ISLM model". Journal of Econometrics, 63, pp. 7-36.

Johansen, S. (1995), Likelihood-Based Inference in Cointegrated Vector Autoregressive Models. New York.

Krugman, P. (1985), “A 'Technology Gap' Model of International Trade”, in Jungenfelt, K., Hague, D., ed., Structural Adjustment in Developing Economies, pp. 35-49.

MacKinnon, J. G., Haug, A. A., Michelis, L. (1999), "Numerical Distribution Functions of Likelihood Ratio Tests for Cointegration". Journal of Applied Econometrics, 14 (5), pp. 563-577.

Meurers, M. (2004), "Estimating Supply and Demand Functions in International Trade: A Multivariate Cointegration Analysis for Germany". Jahrbücher für Nationalökonomie und Statistik, 224 (5), pp. 530-556.

Möller, H., Jarchow, H. J. (1990), "Demand and Supply Functions for West-German Exports". Jahrbücher für Nationalökonomie und Statistik, 207 (6), pp. 529-538.

Pantula, S. G. (1989), "Testing for Unit Roots in Time Series Data”. Econometric Theory, 5, pp. 256-271.

Perron, P. (1988), "Trends and Random Walks in Macroeconomic Time Series. Further Evidence from a New Approach". Journal of Economic Dynamics and Control, 12, pp. 297-332.

Rogoff, K. (2006), "Impact of Globalization on Monetary Policy". Paper prepared for symposium sponsored by the Federal Reserves Bank of Kansas City. http://www.econ.yale.edu/conference/okun/rogoff.paper.0829.pdf. 
Said, S., Dickey, D. (1984), "Testing for Unit Roots in Autoregressive Moving Average Models of Unknown Order". Biometrica, 71 (3), pp. 599-607.

Samuelson, P. A. (2004), "Where Ricardo and Mill Rebut and Confirm Arguments of Mainstream Economists Supporting Globalization". Journal of Economic Perspectives, 18 (3), pp. 135-146.

Stern, R., Francis, J., Schumacher, B. (1976), Price Elasticities in International Trade: An Annotated Bibilography. London.

Strauß, H. (2004), "Demand and Supply of Aggregate Exports of Goods and Services. Multi-variate Cointegration Analyses for the United States, Canada, and Germany". Kieler Studien, No. 329. Berlin et al.

\section{Appendix}

Table A 1

Acronyms of Variables and Data Description

\begin{tabular}{|c|c|c|}
\hline Acronym & Meaning & Source \\
\hline ex & $\log$ of real exports (SITC 5-8) in $€$ & $\begin{array}{l}\text { OECD Monthly Statistics of } \\
\text { International Trade }\end{array}$ \\
\hline $\mathrm{y}$ & $\begin{array}{l}\text { log of real imports (SITC 5-8) from export } \\
\text { market in } €\end{array}$ & $\begin{array}{l}\text { OECD Monthly Statistics of } \\
\text { International Trade }\end{array}$ \\
\hline pex & $\begin{array}{l}\text { log of domestic export unit value index of } \\
\text { machinery and transport equipment in } €\end{array}$ & $\begin{array}{l}\text { OECD Monthly Statistics of } \\
\text { International Trade }\end{array}$ \\
\hline pex_comp & $\begin{array}{l}\text { log of trade-weighted foreign export unit value } \\
\text { index of machinery and transport equipment in } \\
\text { national currencies }\end{array}$ & $\begin{array}{l}\text { OECD Monthly Statistics of } \\
\text { International Trade }\end{array}$ \\
\hline ppi & $\log$ of domestic producer price index in $€$ & OECD Main Economic Indicators \\
\hline wexr & $\begin{array}{l}\text { log of trade-weighted nominal effective } \\
\text { exchange rate index ( } € / \text { national currencies) }\end{array}$ & $\begin{array}{l}\text { OECD Monthly Statistics of } \\
\text { International Trade }\end{array}$ \\
\hline ulc & $\begin{array}{l}\text { log of unit labour costs index in manufacturing } \\
\text { industry in } €\end{array}$ & OECD Main Economic Indicators \\
\hline $\mathrm{ms}$ & $\begin{array}{l}\text { log of market share of CEEC in the export } \\
\text { market including GY }\end{array}$ & $\begin{array}{l}\text { OECD Monthly Statistics of } \\
\text { International Trade }\end{array}$ \\
\hline fdi & $\begin{array}{l}\text { log of inward FDI relative to GDP of the } \\
\text { CEEC }\end{array}$ & OECD Main Economic Indicators \\
\hline $\mathrm{g}$ & $\begin{array}{l}\text { log of exports (volume) relative to GDP } \\
\text { (volume) of the export market }\end{array}$ & OECD Main Economic Indicators \\
\hline
\end{tabular}


Table A 2

LR Results for Hypothesis Tests

\begin{tabular}{|c|c|c|c|}
\hline Ho & $\begin{array}{l}\text { ulc has no impact on export demand, y no impact } \\
\text { on export supply } \\
2.71\end{array}$ & $\begin{array}{l}\text { H0 } \\
\text { LR test }\end{array}$ & $\begin{array}{l}\text { pex is weakly exogenous } \\
16.56 \quad \chi^{2}(2)\end{array}$ \\
\hline $\begin{array}{l}\text { H0 } \\
\text { LR test }\end{array}$ & $\begin{array}{l}\text { ms has no impact on export demand } \\
3.81 \\
\chi^{2}(1)\end{array}$ & $\begin{array}{l}\text { H0 } \\
\text { LR test }\end{array}$ & $\begin{array}{l}\text { pex_comp is weakly exogenous } \\
2.71 \quad \chi^{2}(2)\end{array}$ \\
\hline $\begin{array}{l}\text { H0 } \\
\text { LR test }\end{array}$ & $\begin{array}{l}\text { long-run export supply is infinitely price elastic } \\
11.71\end{array}$ & $\begin{array}{l}\text { H0 } \\
\text { LR test }\end{array}$ & $\begin{array}{l}\text { ulc is weakly exogenous } \\
14.07 \quad \chi^{2}(2)\end{array}$ \\
\hline $\begin{array}{l}\text { H0 } \\
\text { LR test }\end{array}$ & $\begin{array}{l}\text { there is no influence of pex_comp on export supply } \\
8.81\end{array}$ & $\begin{array}{l}\mathrm{H} 0 \\
\text { LR test }\end{array}$ & $\begin{array}{l}\text { ms is weakly exogenous } \\
13.15 \quad \chi^{2}(2)\end{array}$ \\
\hline $\begin{array}{l}\mathrm{H} 0 \\
\text { LR test }\end{array}$ & $\begin{array}{l}\text { ms has no influence on Germany } \\
24.52\end{array}$ & $\begin{array}{l}\text { H0 } \\
\text { LR test }\end{array}$ & $\begin{array}{l}y \text { is weakly exogenous } \\
13.23 \quad \chi^{2}(2)\end{array}$ \\
\hline $\begin{array}{l}\mathrm{H} 0 \\
\text { LR test }\end{array}$ & $\begin{array}{l}\text { ex is weakly exogenous } \\
10.85\end{array}$ & & \\
\hline
\end{tabular}

Table A 3

Cointegration and Loading Coefficients of Model (1)

\begin{tabular}{|c|c|c|c|c|c|c|c|c|}
\hline \multicolumn{7}{|c|}{ cointegrating coefficients } & \multirow{2}{*}{\multicolumn{2}{|c|}{ Test Statistics }} \\
\hline & $\mathrm{EX}(-1)$ & $\operatorname{PEX}(-1)$ & $\begin{array}{c}\text { PEX_- }_{-} \\
\operatorname{COMP(-1)}\end{array}$ & $Y(-1)$ & ULC(-1) & MS(-1) & & \\
\hline $\begin{array}{l}\text { EX-demand } \\
\text { t-value }\end{array}$ & $\begin{array}{l}1 \\
- \\
\end{array}$ & $\begin{array}{c}3.30 * \\
(-3.05)\end{array}$ & $\begin{array}{r}-0.47 \\
(0.84)\end{array}$ & $\begin{array}{l}-0.64 * \\
(9.07)\end{array}$ & $\begin{array}{l}0 \\
- \\
\end{array}$ & $\begin{array}{l}0 \\
- \\
\end{array}$ & \multirow{3}{*}{$\begin{array}{l}\text { Adj. R-squared } \\
\text { EX-demand } \\
\text { Adj. R-squared } \\
\text { EX-supply } \\
\text { LM (1) }\end{array}$} & 0.77 \\
\hline $\begin{array}{l}\text { EX-supply } \\
\text { t-value }\end{array}$ & $\begin{array}{l}-0.44 * \\
(5.37)\end{array}$ & $\begin{array}{r}1 \\
- \\
\end{array}$ & $\begin{array}{l}-0.67^{*} \\
(6.04)\end{array}$ & $\begin{array}{r}0 \\
- \\
\end{array}$ & $\begin{array}{c}0.78 * \\
(-3.24)\end{array}$ & $\begin{array}{c}0.52 * \\
(-6.73)\end{array}$ & & 0.41 \\
\hline \multicolumn{7}{|c|}{ loading coefficients } & & $30.80(0.72)$ \\
\hline & $\Delta \mathbf{E X}$ & $\triangle$ PEX & $\begin{array}{l}\triangle \mathrm{PEX}_{-} \\
\text {COMP }\end{array}$ & $\Delta \mathbf{Y}$ & $\Delta \mathbf{U L C}$ & $\Delta \mathbf{M S}$ & \multirow{4}{*}{$\begin{array}{l}\text { LM (4) } \\
\text { Jarque-Bera } \\
\text { White Test } \\
\text { LR test for joint } \\
\text { restricitions }\left(\chi^{2}(3)\right)\end{array}$} & $29.48(0.77)$ \\
\hline $\begin{array}{l}\text { EX-demand } \\
\text { t-value }\end{array}$ & $\begin{array}{l}-0.16^{*} \\
(1.65)\end{array}$ & $\begin{array}{l}-0.01 \\
(0.42)\end{array}$ & $\begin{array}{l}0 \\
-\end{array}$ & $\begin{array}{l}-0.31 * \\
(5.01)\end{array}$ & $\begin{array}{l}-0.01 \\
(1.04)\end{array}$ & $\begin{array}{c}0.37 * \\
(-2.39)\end{array}$ & & $\begin{array}{l}2.62(0.27) \\
8.54(0.36)\end{array}$ \\
\hline $\begin{array}{l}\text { EX-supply } \\
\text { t-value }\end{array}$ & $\begin{array}{c}0.64 * \\
- \\
\end{array}$ & $\begin{array}{l}-0.28 * \\
(3.85)\end{array}$ & $\begin{array}{l}0 \\
- \\
\end{array}$ & $\begin{array}{c}0.81 * \\
(-5.31)\end{array}$ & $\begin{array}{c}0.04 * \\
(2.37)\end{array}$ & $\begin{array}{l}-1.05^{*} \\
(3.12)\end{array}$ & & \multirow{2}{*}{$\begin{array}{l}7.43(0.06) \\
\text { (p-values) }\end{array}$} \\
\hline & & & & & & & & \\
\hline
\end{tabular}

Note: * significant at the $5 \%$-level. 